International Journal of Instruction e-ISSN: 1308-1470 • www.e-iji.net

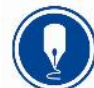

October $2021 \bullet$ Vol.14, No.4

p-ISSN: 1694-609X

pp. 241-258

Article submission code

20200904083833

Received: 04/09/2020

Revision: 07/03/2021

Accepted: 01/04/202

OnlineFirst: 17/07/2021

\title{
Biodiversity Learning Continuum for Elementary School Students Based on Teacher Cognitive Ability
}

\section{Riza Sativani Hayati}

Postgraduate School Student, Universitas Negeri Yogyakarta \& Universitas Muhammadiyah Makassar, Indonesia, rizasativani.hayati@unismuh.ac.id

Bambang Subali

Prof., Biology Education Department, Universitas Negeri Yogyakarta, Indonesia, bambangsubali@uny.ac.id

\section{Paidi}

Dr., Biology Education Department, Universitas Negeri Yogyakarta, Indonesia, paidi@uny.ac.id

\begin{abstract}
An evaluation of the national curriculum by practitioners suggests that learning materials across school levels still overlap, are irrelevant to student development phases and competencies required, too challenging for students to learn, too broad in terms of topics, and lacking in depth. This evaluation encourages the needs for special studies regarding the sequence of the materials - known as a learning continuum - to be taught to students to fit students' learning development, so that learning becomes more effective. The study aims to develop a biology learning continuum on the biodiversity topic for elementary school (ES) students. In this developmental research, the learning continuum was developed based on (1) the survey results regarding the cognitive ability of the 240 participating teachers, (2) group discussion results considering the stages of student cognitive development, cognitive levels and dimensions of materials, and (3) Biological science curriculum study (BSCS) as the standardized biology learning materials. The study has successfully developed 32 sub-topics in the learning continuum which were transformed into only 31 sub-topics at the cognitive level of $\mathrm{C} 1$ and $\mathrm{C} 2$, and the cognitive dimensions of fact and concept knowledge. This learning continuum is expected to help the development of a spiral curriculum in ES for more effective learning.
\end{abstract}

Keywords: biology learning instruction, curriculum development, curriculum evaluation, learning continuum, instruction, learning

\section{INTRODUCTION}

Curriculum is a significant part of the education process. Curriculum is the purpose, design, and implementation of the program (Bouckaert and Kools, 2018), usually set out

Citation: Hayati, R. S., Subali, B., \& Paidi. (2021). Biodiversity Learning Continuum for Elementary School Students Based on Teacher Cognitive Ability. International Journal of Instruction, 14(4), 241258. https://doi.org/10.29333/iji.2021.14415a 
in a syllabus which contains a sequence of materials offered by a particular field of study at school (Westbury et al., 2016). The educational reform process must be followed by continuous curriculum development through reviews, revisions, and changes (Alsubaie, 2016). In Indonesia, graduate competency standards and curriculum content standards are determined by the government in the content standards as listed in the national education standards. The national standard contains a minimum standard of materials that should be mastered by students.

It has been widely known that the school curriculum applied in Indonesia is a spiral one. The concept of a spiral curriculum was introduced by Jerome Bruner (Liu, 2016) stating that the curriculum is built from basic things gradually introduced to students to make them fully and deeply understood. Effective learning begins with what students already know and the teacher provides guidance that advances their thinking, so teachers need to identify students' current knowledge to help identify the next steps they need to learn (Ivars, et al, 2018). This spiral curriculum presents the material in repeated learning opportunities over time, and the materials are organized from simple to complex (Murray, 2016), from general to specific, and are assessed in relation to one another. According to Bruner, the spiral curriculum helps students to organize knowledge into structures that make it more accessible and can be used in areas outside of direct learning situations (Liu, 2016).

The content standards of the curriculum set by the government need to be reviewed as the application of the spiral curriculum principles is still questionable in the 2013 Curriculum. There are still many curriculum evaluation reports from teachers and education practitioners stating that the existing learning materials still overlap (Juniati and Subali, 2017), irrelevant to the student development (Faisal and Martin, 2019), irrelevant to required competencies, too difficult for students to learn, too broad in terms of topics, and lack depth (Astuti and Subali, 2017). If curriculum development does not pay attention to the principles of the spiral curriculum, especially sustainability at every level of education, it can lead to ineffective learning processes such as student anxiety while learning (Yuliani, et al, 2018). Therefore, special studies are needed regarding the sequence in which the materials should be taught to students to fit the development of students' learning, so that learning can be more effective. One of the bases for determining the order of the subject matters to learn is the learning continuum.

This research aims to develop a biodiversity learning continuum for the biology learning materials in the Science subject of Elementary School Students (ESs). The Convention on Biodiversity defines biodiversity as the variability among living organisms, including a terrestrial, marine, and aquatic ecosystem. Biodiversity includes genetic diversity, species, and ecosystems (Yli-Panula, et al, 2018). A good biodiversity curriculum will lead to environmental education reform, biodiversity learning will spread awareness to protect biodiversity (Adawiah, et al, 2015). It is expected that the developed biodiversity learning continuum can assist the biology curriculum development to be more in line with students' learning development. For this, the development of the learning continuum in this study was based on the cognitive abilities of the teachers. 


\section{Context and Literature Review \\ Learning Continuum Development}

Learning continuum is a series or sequence of students' abilities (knowledge and skills) developed from the assessment of learning experiences. It is a learning statement that provides an instructional starting point by explaining the skills and concepts that are most ready to be introduced, developed, or reinforced throughout the learning sequence. It can be a strong shortcut to understanding the skills that students are ready to learn, and it helps identify learning goals and targets so that the teacher can develop more personal lesson plans. Teachers can determine where each student is ready to progress and where they need help (Orizasativa et al., 2019), and this maximizes the teacher's support so that all students will perform. Teachers can use learning continuum information to streamline the planning of teaching, differentiate instructions for individual students, and group skill-based activities, as well as involve more students in learning (Wilson, 2014).

The teacher's cognitive abilities, therefore, are also an indication of students' cognitive abilities as students get their cognitive abilities from the teacher. Research from Förtsch, e al, (2016) showed that the competence of biology teachers in the aspects of pedagogical content knowledge and cognitive content knowledge of neurological topics can activate biology learning, thus influencing student learning achievement. This is in line with researchs by Ardiawan (2017) and Fauth et al., (2019) which showed that there was a significant influence between teacher competence, namely the mastery of standard material competencies for students on student achievement in science subjects. Competencies not mastered by the teacher will be less likely to be mastered by students and the most appropriate way of developing a learning continuum, based on this view, is the practitioners' focus of learning. How the learning continuum is used and where the emphasis will be placed clearly depend on teacher job roles, tasks, individual profiles, preferences, learning goals, performance issues, content requirements, organizational culture, etc. (Sinha, 2012). With regard to this, Sultan and Shafi (2014) show that teacher competency can be used to predict student performance. Therefore, the profile of teacher abilities can be one of the bases for preparing a learning continuum. Besides, a learning continuum is arranged based on several things, including the cognitive level of the competency to be achieved, the stages of the student development, and the applied international curriculum standards.

\section{Student Cognitive Development}

Learning students' cognitive development is a foundation of child education. Educating by knowing their cognitive level will influence their readiness and success in the study (Wang and Wang, 2015). The cognitive level of competence pertains to Bloom's revised taxonomy by Anderson and Krathwool consisting of dimensions of cognitive processes: C1 (remember), C2 (understand), C3 (apply), C4 (analyze), C5 (evaluate), and C6 (create), and the knowledge dimensions consist of factual, conceptual, procedural, and metacognitive knowledge (Anderson and Krathwohl, 2001; Paidi et al., 2020). Bloom's taxonomy is arranged for developing tests and assessment (Chandio et al., 2017) that 
can be used to evaluate and develop the curriculum (Assaly and Smadi, 2015). The higher the level of student development, the higher the cognitive level that can be trained to students (Kusumawati et al., 2019).

The stages of student development in the preparation of a learning continuum refer to Piaget's theory regarding the stages of student cognitive development (Blake and Pope, 2008; Ibda, 2015). Piaget explains how children have a cognitive process (Ulu and Kiraz, 2014), and that it is important for teachers to enhance the teaching and learning process (Simatwa, 2010). The stages of cognitive development in elementary school-age students are as follows:

Table 1

Cognitive development of elementary school students

\begin{tabular}{llrl}
\hline Age (year) & Stage of Development & Characteristics \\
\hline $6-11$ & Concrete Operations & a. & $\begin{array}{l}\text { Students are mature enough to use logical thinking or } \\
\text { operations, but only for physical objects that exist today. }\end{array}$ \\
& b. & $\begin{array}{l}\text { Without physical objects in front of them, students still } \\
\text { have great difficulty in completing logic tasks. }\end{array}$ \\
\hline $11-13$ & Formal Operations & a. & $\begin{array}{l}\text { Students can use concrete operations to form more } \\
\text { complex operations. }\end{array}$ \\
& b. & $\begin{array}{l}\text { Students do not need to think with the help of objects or } \\
\text { concrete events, he has the ability to think abstractly. }\end{array}$ \\
& c. & Children are able to understand the form of argument \\
\hline
\end{tabular}

Biology Curriculum Standard on Biodiversity Topic

The international biology curriculum standard is used in the reference for the preparation of this learning continuum is the Biological Science Curriculum Study (BSCS). BSCS is one of the centers for curriculum development and learning of Biology and has produced many documents related to biology learning, such as curricula, books, teacher guidelines, student guidelines, discussion of new topics, reports on research results in Biology education, as well as training programs for biology teachers (Suyanto, 2011). With this BSCS, it is expected that the materials have been standardized according to the needs of the international Biology materials.

Standard materials on the topic of Biodiversity contained in the BSCS Blue Version: A Molecular Approach book, include (1) The Species Concept; (2) Classification and Homologies; (3) The Linnaean Classification System; (4) Ways to Classify Species; (5) Five Kingdoms: Plantae, Animalia, Fungi, Protista, and Monera; (6) Classification and Change. These materials are expected to equip students to be able to (1) define a species and explain the biological meaning of the species; (2) explain homology and give examples of homologous structures; (3) describe the classification hierarchies used to categorize organisms and how they relate to one another; (4) describe ways to classify species; (5) describe how the general characteristics of the five kingdoms differ; and (6) predict the effects of new knowledge on classification systems (BSCS, 2006).

\section{METHOD}

\section{Research Design and Participants}

This study is developmental research. Survey and focus group discussion (FGD) used as its data collecting methods. The respondents of this study consisted of 240 ES teachers 
who were teaching students at grade 1 to 6 in the Special Region of Yogyakarta, including Yogyakarta municipality and three regencies, i.e. Bantul, Sleman, and Kulon Progo. These teachers were given an instrument to assess their cognitive competency on Biodiversity materials. FGD were conducted between researchers and elementary school teachers in grades 1 to 6 and between researchers and biology education experts. The FGD discussed the evaluation of the learning implementation on biodiversity competency national standards. The curriculum is criticized to find the strengths and weaknesses of biodiversity competency and material according to the student cognitive needs. Based on the survey and FGD results, the learning continuum was successfully developed. Its development was in accordance with the results of the initial study with experts in Biology education and the FGD contributed by ES teachers. The protection of the privacy of research participants and the confidentiality of the institutions participating in the research are guaranteed.

Table 2

The identity of respondents

\begin{tabular}{lll}
\hline Respondent Criteria & & Number of Respondents \\
\hline Grade of Teaching & Grade 1 & 41 \\
\cline { 2 - 3 } & Grade 2 & 31 \\
\cline { 2 - 3 } & Grade 3 & 37 \\
\cline { 2 - 3 } & Grade 4 & 33 \\
\cline { 2 - 3 } & Grade 5 & 52 \\
\cline { 2 - 3 } & Grade 6 & 46 \\
\hline
\end{tabular}

\section{Data Collection Instruments}

In preparing the learning continuum, Biodiversity learning materials for ESs requires sorting. Sorting is carried out to select materials suitable for the stages of student cognitive development and the ability of ES teachers to deliver the materials, so that only a few suitable materials were selected from all standard Biodiversity materials in the BSCS. The results of the selections of these materials are contained in the instruments tested on the participating teachers. If these teachers can master the materials, their students will likely be able to understand the materials taught as well.

Questionnaires were distributed to $240 \mathrm{ES}$ teachers to find out the profile of their cognitive competence. They covers 32 cognitive competency items on biodiversity materials that were arranged based on the learning continuum draft. Meanwhile, the learning continuum draft was arranged based on the BSCS and was discussed with two biology education experts. The questionnaire items are in the form of multiple-choice questions and the responding teachers are obliged to give explanations or reasons for each item, why they answer the chosen point, A, B, or C. Previously, this instrument had passed the expert validation stage involving the biology education experts.

\section{Data Analysis Procedure}

The test results were analyzed quantitatively using the Rasch model with the Quest application. In this process, a question item was analyzed using the item response theory (IRT). Other names for IRT include Latent Trait Theory (LTT) or Characteristics Curve 
Theory (CCT), a theory that uses mathematical functions to connect the opportunity of answering a question correctly with the respondent's abilities (Bond and Fox, 2017). The IRT model used in this study is Rasch Model, a one-parameter model which is to analyze data that only focus on the difficulty level parameters (Adams and Kho, 1996). The Quest application is a type of computer programs used for analyzing items with a modern one-parameter approach.

In addition, the results of the FGD were analyzed descriptively. The results of this FGD were in the form of evaluations of the ES Biology science learning, input, or suggestions regarding the order of the existing learning materials in the national curriculum, as well as an overview of the learning process and student learning outcomes with the material sequence in the national curriculum.

\section{FINDINGS}

The draft of the learning continuum for the Biodiversity topic was developed and tested on the targeted teachers to determine their ability in each competency. The item of test was developed based on the learning continuum draft with the following details.

Table 3

Description of item that developed from learning continuum draft

\begin{tabular}{|c|c|c|c|}
\hline Item & Aspect & Question Indicator & $\begin{array}{l}\text { Cognitive } \\
\text { Level }\end{array}$ \\
\hline 1 & $\begin{array}{l}\text { Morphological diversity of human bodies: } \\
\text { similarities and differences }\end{array}$ & $\begin{array}{l}\text { Showing differences in the human body in } \\
\text { morphological diversity }\end{array}$ & $\mathrm{C} 2$ \\
\hline 2 & $\begin{array}{l}\text { Factors affecting the morphological diversity } \\
\text { of human bodies: similarities and differences }\end{array}$ & $\begin{array}{l}\text { Mentioning the morphological } \\
\text { characteristics inherited by genetic factors }\end{array}$ & $\mathrm{C} 2$ \\
\hline 3 & $\begin{array}{l}\text { Morphological diversity of animal's bodies: } \\
\text { similarities and differences }\end{array}$ & $\begin{array}{l}\text { Showing differences in animal bodies in } \\
\text { morphological diversity }\end{array}$ & $\mathrm{C} 2$ \\
\hline 4 & $\begin{array}{l}\text { Factors affecting the morphological diversity } \\
\text { of the animal's bodies: similarities and } \\
\text { differences }\end{array}$ & $\begin{array}{l}\text { Mentioning animals' morphological } \\
\text { characteristics which are inherited by } \\
\text { genetic factors }\end{array}$ & $\mathrm{C} 2$ \\
\hline 5 & $\begin{array}{l}\text { Morphological diversity of organs (head, neck, } \\
\text { body, and locomotor) of humans and animals: } \\
\text { similarities and differences }\end{array}$ & $\begin{array}{l}\text { Showing the morphological diversity of } \\
\text { body organs }\end{array}$ & $\mathrm{C} 1$ \\
\hline 6 & $\begin{array}{l}\text { Morphological diversity of flowering plant } \\
\text { bodies: similarities and differences }\end{array}$ & $\begin{array}{l}\text { Mentioning the shape differences in the } \\
\text { morphological diversity of flowering plant } \\
\text { bodies }\end{array}$ & $\mathrm{C} 1$ \\
\hline 7 & $\begin{array}{l}\text { Factors affecting the morphological diversity } \\
\text { of flowering plant bodies: similarities and } \\
\text { differences }\end{array}$ & $\begin{array}{l}\text { Understanding the flowering plant bodies' } \\
\text { morphological differences inherited from } \\
\text { their parents }\end{array}$ & $\mathrm{C} 2$ \\
\hline 8 & $\begin{array}{l}\text { Morphological diversity of organs (roots, } \\
\text { stems, leaves, flowers, fruits, and seeds) in } \\
\text { flowering plants: similarities and differences }\end{array}$ & $\begin{array}{l}\text { Identifying the morphological diversity of } \\
\text { flower organs in flowering plants }\end{array}$ & $\mathrm{C} 1$ \\
\hline 9 & $\begin{array}{l}\text { Morphological diversity of ferns: similarities } \\
\text { and differences }\end{array}$ & $\begin{array}{l}\text { Identifying the morphological diversity of } \\
\text { the body of the ferns }\end{array}$ & $\mathrm{C} 1$ \\
\hline 10 & $\begin{array}{l}\text { Morphological diversity of mosses' bodies: } \\
\text { similarities and differences }\end{array}$ & $\begin{array}{l}\text { Identifying the morphological diversity of } \\
\text { the moss plant body }\end{array}$ & $\mathrm{C} 1$ \\
\hline 11 & $\begin{array}{l}\text { Morphological diversity of algae bodies (plant- } \\
\text { like protists): similarities and differences }\end{array}$ & $\begin{array}{l}\text { Identifying the morphological diversity of } \\
\text { the body of seaweed plants }\end{array}$ & $\mathrm{C} 1$ \\
\hline 12 & Morphological diversity of mushroom bodies: & Identifying the morphological differences & $\mathrm{C} 1$ \\
\hline
\end{tabular}




\begin{tabular}{|c|c|c|c|}
\hline & similarities and differences & $\begin{array}{l}\text { in the body of mushrooms consumed in } \\
\text { daily life }\end{array}$ & \\
\hline 13 & $\begin{array}{l}\text { Biome diversity (desert, forest, steppe, } \\
\text { savanna, taiga, tundra, etc.), similarities and } \\
\text { differences }\end{array}$ & $\begin{array}{l}\text { Identifying types of biomes from the } \\
\text { features provided }\end{array}$ & $\mathrm{C} 1$ \\
\hline 14 & $\begin{array}{l}\text { Factors affecting Biome diversity (desert, } \\
\text { forest, steppe, savanna, taiga, tundra, etc.). }\end{array}$ & $\begin{array}{l}\text { Understanding the factors influencing } \\
\text { differences in various biomes }\end{array}$ & $\mathrm{C} 2$ \\
\hline 15 & $\begin{array}{l}\text { Terrestrial ecosystem diversity: similarities and } \\
\text { differences }\end{array}$ & $\begin{array}{l}\text { Mentioning ecosystems included in the } \\
\text { diversity of terrestrial ecosystems }\end{array}$ & $\mathrm{C} 1$ \\
\hline 16 & $\begin{array}{l}\text { Diversity of aquatic ecosystems: similarities } \\
\text { and differences }\end{array}$ & $\begin{array}{l}\text { Mentioning ecosystems included in the } \\
\text { diversity of aquatic ecosystems }\end{array}$ & $\mathrm{C} 1$ \\
\hline 17 & $\begin{array}{l}\text { Factors affecting ecosystem diversity (land and } \\
\text { water) }\end{array}$ & $\begin{array}{l}\text { Determining factors affecting terrestrial } \\
\text { ecosystem diversity }\end{array}$ & $\mathrm{C} 2$ \\
\hline 18 & $\begin{array}{l}\text { Community diversity: similarities and } \\
\text { differences }\end{array}$ & $\begin{array}{l}\text { Mentioning one type of community in } \\
\text { terrestrial ecosystems }\end{array}$ & $\mathrm{C} 2$ \\
\hline 19 & $\begin{array}{l}\text { Diversity of populations in human, animals, } \\
\text { plants, fungi, protists, monera, bacteria: } \\
\text { similarities and differences }\end{array}$ & $\begin{array}{l}\text { Identifying populations in marine } \\
\text { ecosystems }\end{array}$ & $\mathrm{C} 2$ \\
\hline 20 & $\begin{array}{l}\text { The diversity of individuals in populations of } \\
\text { human, animals, plants, fungi, protists, } \\
\text { monera, bacteria: similarities and differences }\end{array}$ & $\begin{array}{l}\text { Identifying differences in individual } \\
\text { diversity in animal populations }\end{array}$ & $\mathrm{C} 1$ \\
\hline 21 & $\begin{array}{l}\text { Factors affecting individual diversity in human } \\
\text { populations, animals, plants, fungi, protists, } \\
\text { and monera }\end{array}$ & $\begin{array}{l}\text { Knowing genetic factors as determinants } \\
\text { of morphological features in individual } \\
\text { diversity in animal populations }\end{array}$ & $\mathrm{C} 2$ \\
\hline 22 & $\begin{array}{l}\text { The diversity of flora in the oriental zone } \\
\text { (western Indonesia): their similarities and } \\
\text { differences }\end{array}$ & $\begin{array}{l}\text { Mentioning the diversity of flora in the } \\
\text { oriental zone (western Indonesia) }\end{array}$ & $\mathrm{C} 1$ \\
\hline 23 & $\begin{array}{l}\text { The diversity of flora of the Australasian zone } \\
\text { (eastern Indonesia): similarities and } \\
\text { differences }\end{array}$ & $\begin{array}{l}\text { Mentioning the diversity of flora in the } \\
\text { Australasian zone (eastern Indonesia) }\end{array}$ & $\mathrm{C} 1$ \\
\hline 24 & $\begin{array}{l}\text { The diversity of flora in the transition zone } \\
\text { (central Indonesia): similarities and differences }\end{array}$ & $\begin{array}{l}\text { Identifying the diversity of flora in the } \\
\text { transition zone (central Indonesia) }\end{array}$ & $\mathrm{C} 1$ \\
\hline 25 & Rare flora types: similarities and differences & Mentioning rare flora types & $\mathrm{C} 1$ \\
\hline 26 & $\begin{array}{l}\text { Endemic flora types: similarities and } \\
\text { differences }\end{array}$ & $\begin{array}{l}\text { Mentioning the type of endemic flora in } \\
\text { Indonesia }\end{array}$ & $\mathrm{C} 1$ \\
\hline 27 & $\begin{array}{l}\text { The diversity of oriental zone fauna (western } \\
\text { Indonesia): similarities and differences }\end{array}$ & $\begin{array}{l}\text { Mentioning the characteristics of fauna } \\
\text { diversity in the oriental zone (western } \\
\text { Indonesia) }\end{array}$ & $\mathrm{C} 1$ \\
\hline 28 & $\begin{array}{l}\text { The diversity of fauna in the Australasian zone } \\
\text { (eastern Indonesia): similarities and } \\
\text { differences }\end{array}$ & $\begin{array}{l}\text { Identifying the Australasian zone fauna } \\
\text { (eastern Indonesia) }\end{array}$ & $\mathrm{C} 1$ \\
\hline 29 & $\begin{array}{l}\text { The diversity of the transition zone fauna } \\
\text { (central Indonesia): similarities and differences }\end{array}$ & $\begin{array}{l}\text { Identifying transitional zone fauna (central } \\
\text { Indonesia) }\end{array}$ & $\mathrm{C} 1$ \\
\hline 30 & Rare fauna types: similarities and differences & Mentioning rare fauna species in Indonesia & $\mathrm{C} 1$ \\
\hline 31 & $\begin{array}{l}\text { Endemic fauna types: similarities and } \\
\text { differences }\end{array}$ & $\begin{array}{l}\text { Mentioning types of endemic Indonesian } \\
\text { fauna }\end{array}$ & $\mathrm{C} 1$ \\
\hline 32 & $\begin{array}{l}\text { Ecosystem diversity in Indonesia: similarities } \\
\text { and differences }\end{array}$ & $\begin{array}{l}\text { Mentioning one of the diversity of } \\
\text { ecosystems in Indonesia }\end{array}$ & $\mathrm{C} 1$ \\
\hline
\end{tabular}

The analysis results of the survey data through Quest discussed in this study are the output part consisting of the suitability of instrument items with the Rasch model, the level of difficulty of the test items, the reliability of the questions, and the estimation of the respondent's abilities. First, the compatibility of items with the Rasch model can be 
seen from the infit means square value (INFIT MNSQ) or the value of INFIT $t$ and the outfit value of the item concerned. Items that match the Rasch model have an INFIT MNSQ of $0.77-1.30$, and the outfit value of $t \leq 2$. From Figure 1 below, it is evident that the INFIT value of MNSQ is 1.00 , meaning that, overall, the items fit the Rasch model.

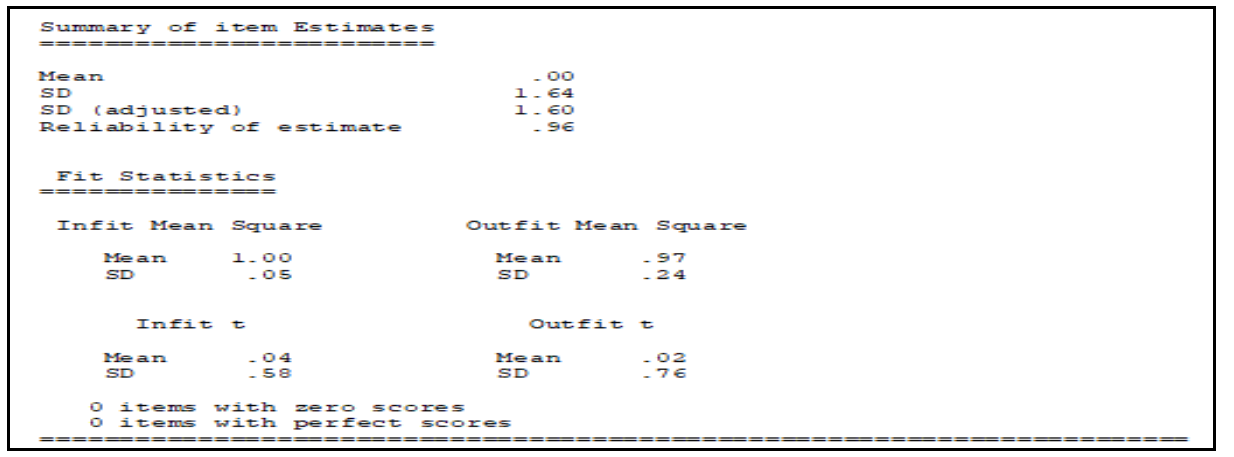

Figure 1

Data analysis results: summary of item estimates

Besides, Figure 2 below depicts that all items in the learning continuum instrument are stated to be compatible with the Rasch model as proven by the MNSQ INFIT value between $0.77-1.30$.

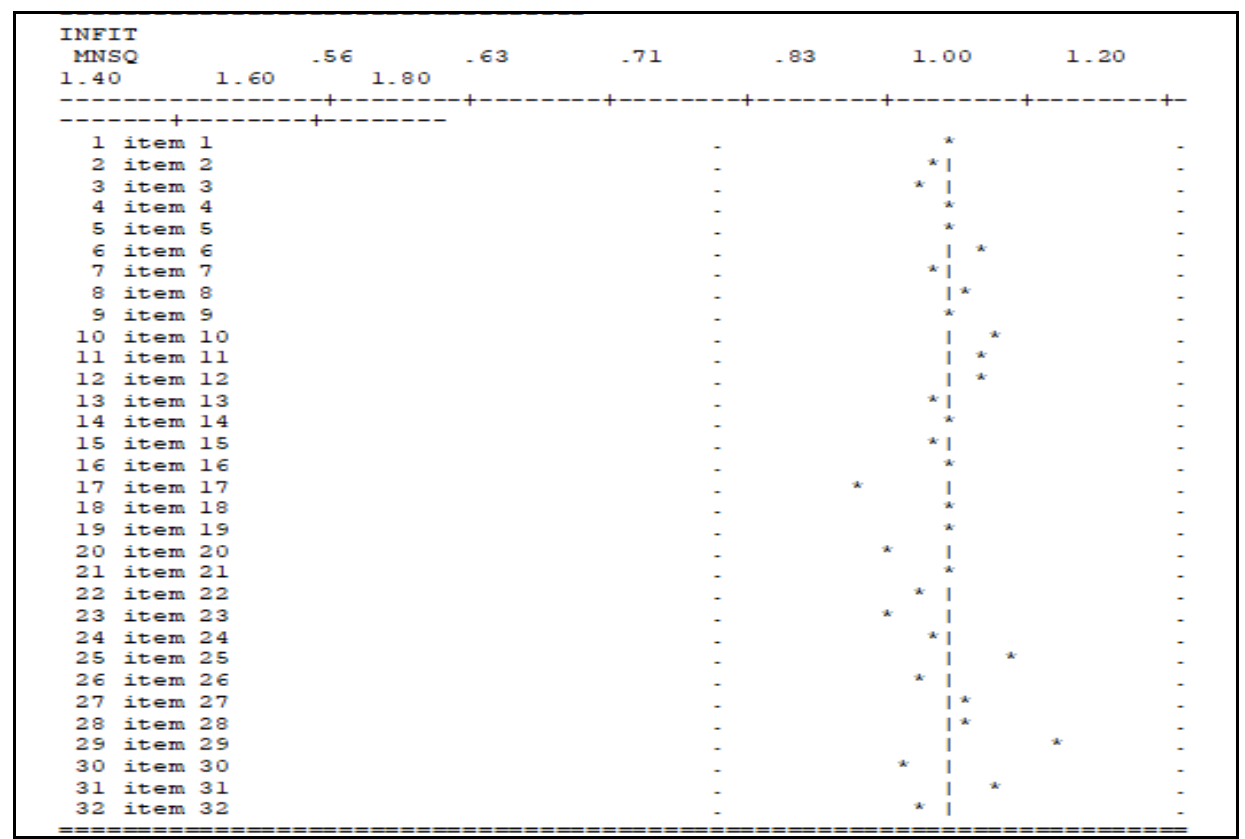

Figure 2

MNSQ INFIT value showing that all items fit 
Second, the level of difficulty of the test items can be seen from the threshold value that presented on Table 3. Based on the threshold value, the level of difficulty of each item can be categorized into several criteria presented on Table 4. Distribution of difficulty levels of the questions and the ability of respondents can be seen in the map presented in Figure 3. The difficulty level and level of ability of these students are on one line so that the continuum developed can recognize the position of each subject to the difficulty level of the item being worked on. Figure 3 below presents the distribution of respondents according to their ability level and the distribution of items according to their level of difficulty in logit -2.0 to +2.0 .

Table 3

Preliminary learning continuum survey results based on teachers' cognitive ability

\begin{tabular}{|c|c|c|}
\hline Item & Teachers' Cognitive Ability (\%) & Level of Difficulty (Thresholds) \\
\hline 1 & $98.75 \%$ & -2.28 \\
\hline 2 & $89.17 \%$ & -0.03 \\
\hline 3 & $95.00 \%$ & -0.87 \\
\hline 4 & $97.92 \%$ & -1.77 \\
\hline 5 & $38.33 \%$ & 2.74 \\
\hline 6 & $85.00 \%$ & 0.36 \\
\hline 7 & $82.50 \%$ & 0.55 \\
\hline 8 & $97.50 \%$ & -1.59 \\
\hline 9 & $97.50 \%$ & -1.59 \\
\hline 10 & $81.67 \%$ & 0.61 \\
\hline 11 & $80.83 \%$ & 0.67 \\
\hline 12 & $62.08 \%$ & 1.68 \\
\hline 13 & $98.33 \%$ & -1.99 \\
\hline 14 & $87.92 \%$ & 0.1 \\
\hline 15 & $97.92 \%$ & -1.77 \\
\hline 16 & $99.17 \%$ & -2.68 \\
\hline 17 & $64.58 \%$ & 1.56 \\
\hline 18 & $96.67 \%$ & -1.29 \\
\hline 19 & $97.92 \%$ & -1.77 \\
\hline 20 & $68.33 \%$ & 1.38 \\
\hline 21 & $91.67 \%$ & -0.32 \\
\hline 22 & $58.75 \%$ & 1.83 \\
\hline 23 & $86.67 \%$ & 0.21 \\
\hline 24 & $63.75 \%$ & 1.6 \\
\hline 25 & $91.67 \%$ & -0.32 \\
\hline 26 & $73.75 \%$ & 1.1 \\
\hline 27 & $70.42 \%$ & 1.27 \\
\hline 28 & $92.50 \%$ & -0.44 \\
\hline 29 & $15.83 \%$ & 4.03 \\
\hline 30 & $80.00 \%$ & 0.72 \\
\hline 31 & $75.83 \%$ & 0.98 \\
\hline 32 & $99.17 \%$ & -2.68 \\
\hline
\end{tabular}


Table 4

Thresholds' value criteria/b value (Adams and Kho, 1996)

\begin{tabular}{lll}
\hline Thresholds Value & Criteria & Total Item \\
\hline $\mathrm{b}>2$ & Very Difficult & 2 \\
\hline $1<\mathrm{b} \leq 2$ & Difficult & 6 \\
\hline$-1<\mathrm{b} \leq 1$ & Medium & 14 \\
\hline$-1>\mathrm{b} \geq-2$ & Easy & 7 \\
\hline $\mathrm{b}<-2$ & Very Easy & 3 \\
\hline
\end{tabular}

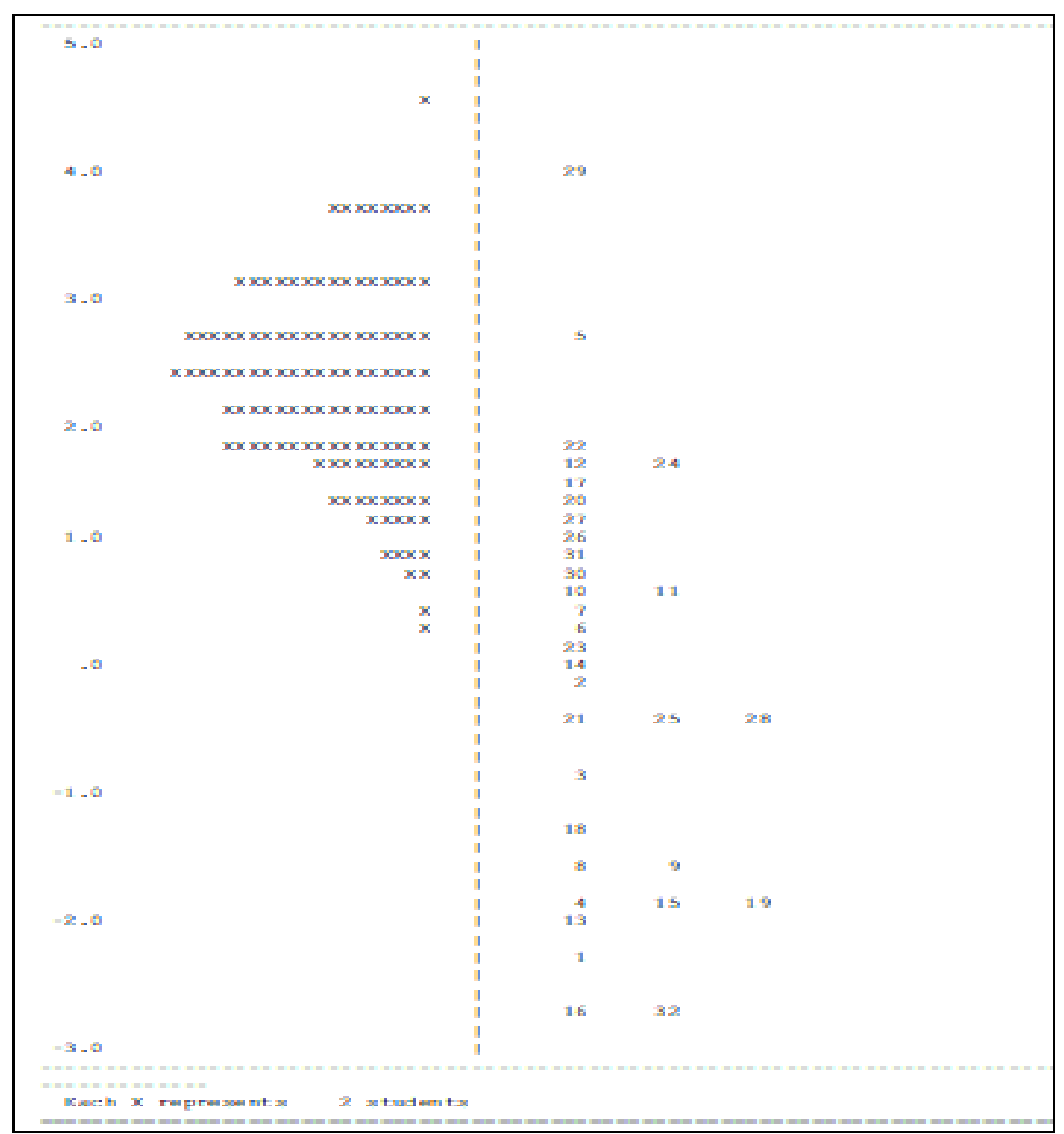

Figure 3

Thresholds of item estimates 
Based on Figure 3, of the 32 items developed, there are two very difficult items and 3 very easy questions. Test item number 29 is considered the most difficult one and numbers 16 and 32 are the easiest. There are 8 items classified as very difficult and difficult, and these items need to be well thought out on ES learning.

Third, the items' reliability value is 0.96 and the reliability value of the cases or testees is 0.42 , as seen in Figure 1 and 4 . These values indicate that the test items are considered to have very high reliability and the measurement provides consistent results. Based on the three parameters above, this study shows that the obtained results of the analysis with the Quest program for both items and testees are fit, accompanied by the reliability of the test instrument.

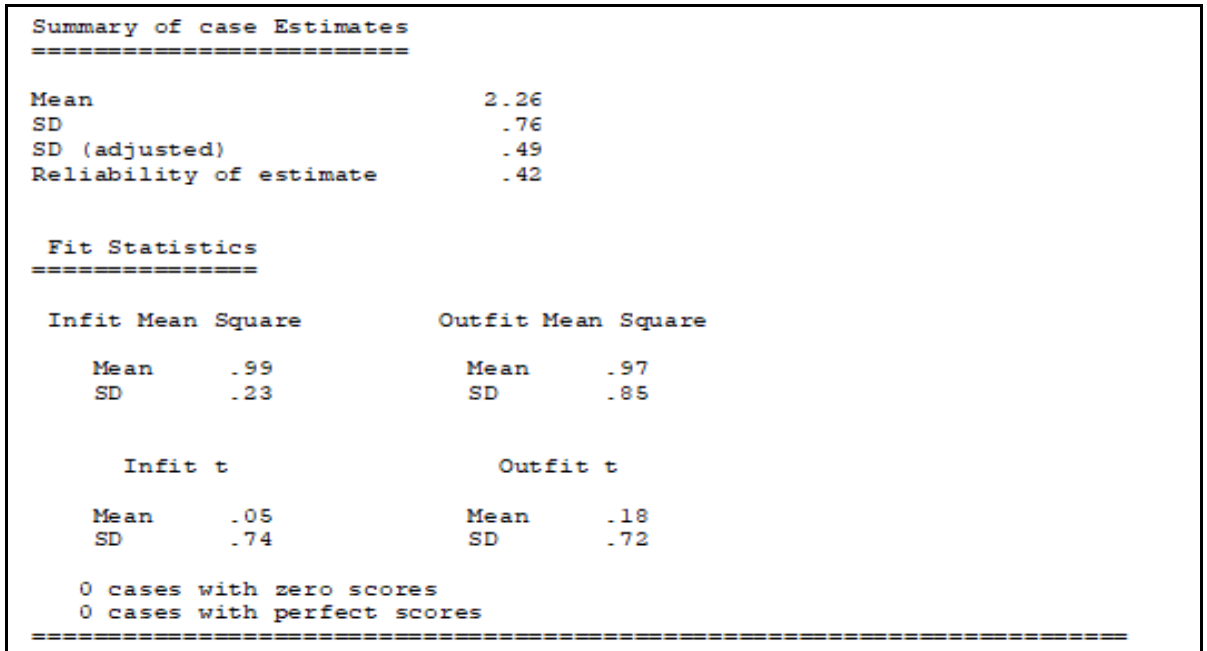

Figure 4

Case estimates

The following is the final biodiversity learning continuum of elementary schools developed based on the results of the analysis of the teacher's survey data, the results of the focus group discussion, principles of cognitive dimension, and the stages of student development. 
Table 5

The final biodiversity learning continuum

\begin{tabular}{|c|c|c|c|c|}
\hline \multirow{2}{*}{$\begin{array}{l}\text { To } \\
\text { Teach in } \\
\text { ES } \\
\text { Grade } \\
\end{array}$} & \multirow[t]{2}{*}{ Biodiversity Aspect } & \multirow[t]{2}{*}{$\begin{array}{l}\text { Cognitive } \\
\text { Level }\end{array}$} & \multicolumn{2}{|c|}{$\begin{array}{l}\text { Knowledge } \\
\text { Dimension }\end{array}$} \\
\hline & & & Fact & Concept \\
\hline \multirow[t]{4}{*}{1} & Ecosystem diversity in Indonesia & $\mathrm{C} 1$ & $\sqrt{ }$ & \\
\hline & Terrestrial ecosystem diversity & $\mathrm{C} 1$ & $\sqrt{ }$ & \\
\hline & Diversity of aquatic ecosystems & $\mathrm{C} 1$ & $\sqrt{ }$ & \\
\hline & Factors affecting ecosystem diversity & $\mathrm{C} 2$ & & $\sqrt{ }$ \\
\hline \multirow[t]{2}{*}{2} & Morphological diversity of human bodies & $\mathrm{C} 2$ & $\sqrt{ }$ & \\
\hline & $\begin{array}{l}\text { Factors affecting the morphological diversity of } \\
\text { human bodies }\end{array}$ & $\mathrm{C} 2$ & & $\sqrt{ }$ \\
\hline \multirow[t]{2}{*}{3} & Morphological diversity of animal's bodies & $\mathrm{C} 2$ & $\sqrt{ }$ & \\
\hline & $\begin{array}{l}\text { Factors affecting the morphological diversity of the } \\
\text { animal's bodies }\end{array}$ & $\mathrm{C} 2$ & & $\sqrt{ }$ \\
\hline \multirow[t]{7}{*}{4} & Morphological diversity of flowering plant bodies & $\mathrm{C} 1$ & $\sqrt{ }$ & \\
\hline & $\begin{array}{l}\text { Factors affecting the morphological diversity of } \\
\text { flowering plant bodies }\end{array}$ & $\mathrm{C} 2$ & & $\sqrt{ }$ \\
\hline & Morphological diversity of organs in flowering plants & $\mathrm{C} 1$ & $\sqrt{ }$ & \\
\hline & Morphological diversity of ferns & $\mathrm{C} 1$ & $\sqrt{ }$ & \\
\hline & Morphological diversity of mosses' bodies & $\mathrm{C} 1$ & $\sqrt{ }$ & \\
\hline & Morphological diversity of algae bodies & $\mathrm{C} 1$ & $\sqrt{ }$ & \\
\hline & Morphological diversity of mushroom bodies & $\mathrm{C} 1$ & $\sqrt{ }$ & \\
\hline \multirow[t]{6}{*}{5} & Biome diversity & $\mathrm{C} 1$ & $\sqrt{1}$ & \\
\hline & Factors affecting Biome diversity & $\mathrm{C} 2$ & & $\sqrt{ }$ \\
\hline & Community diversity & $\mathrm{C} 2$ & $\sqrt{ }$ & \\
\hline & Diversity of populations & $\mathrm{C} 2$ & $\sqrt{ }$ & \\
\hline & The diversity of individuals in populations & $\mathrm{C} 1$ & $\sqrt{ }$ & \\
\hline & Factors affecting individual diversity & $\mathrm{C} 2$ & & $\sqrt{ }$ \\
\hline \multirow[t]{10}{*}{6} & The diversity of flora in the oriental zone & $\mathrm{C} 1$ & & $\sqrt{ }$ \\
\hline & The diversity of flora in the Australasian zone & $\mathrm{C} 1$ & & $\sqrt{ }$ \\
\hline & The diversity of flora in the transition zone & $\mathrm{C} 1$ & & $\sqrt{ }$ \\
\hline & The diversity of fauna in the oriental zone & $\mathrm{C} 1$ & & $\sqrt{ }$ \\
\hline & The diversity of fauna in the Australasian zone & $\mathrm{C} 1$ & & $\sqrt{ }$ \\
\hline & The diversity of fauna in the transition zone & $\mathrm{C} 1$ & & $\sqrt{ }$ \\
\hline & Rare flora types & $\mathrm{C} 1$ & & $\sqrt{ }$ \\
\hline & Rare fauna types & $\mathrm{C} 1$ & & $\sqrt{ }$ \\
\hline & Endemic flora types & $\mathrm{C} 1$ & & $\sqrt{ }$ \\
\hline & Endemic fauna types & $\mathrm{C} 1$ & & $\sqrt{ }$ \\
\hline
\end{tabular}

The final learning continuum shows that out of 32 items, only 31 items are suitable for the ES level. The 31 items are sorted by level of difficulty to determine which grade the material should be taught at. Cognitive levels are in $\mathrm{C} 1$ and $\mathrm{C} 2$, while the knowledge dimensions was only factual and conceptual knowledge.

International Journal of Instruction, October $2021 \bullet$ Vol.14, No.4 


\section{DISCUSSION}

This study believes that the more items the respondents can answer correctly, the higher the respondent's ability is. The estimated ability of respondents can be seen in the file at the estimated value. The sample teachers participating in this study were 240 , and the analysis results show that 148 respondents $(61.67 \%)$ have very high abilities, 76 (31.67\%) perform high abilities, and 16 (6.67\%) have medium abilities. Thus, it can be understood that the test items reflecting this learning continuum are somewhat in accordance with the ability of the teachers and can predict the ability of their respective students. Changes may only occur in the removal of materials with a threshold value $>2$ or items in the very difficult category as needed.

In view of this, a learning continuum is a sequence of materials adjusted to the ability of students, in this case, predicted by the ability of teachers, so that it is expected to promote effective learning. As the threshold results are already discussed, the material that is very difficult for the teachers can be deleted with the assumption that the item represents sub-topics that cannot be completed by students. Of the 32 items representing 32 sub-topics of the Biodiversity materials, 2 sub-topics that are very difficult for respondents should be reconsidered or to be taken into account whether they will be included in the learning continuum, namely item number 5 and 29. In addition to considering or omitting items with very high difficulty indexes, it is also necessary to pay attention to 6 items in the difficult category, namely item number 12, 17, 20, 22, 24, and 27.

The development of the learning continuum, besides looking at the threshold values, also needs to look at the dimensions of cognitive processes: C1 (remember), C2 (understand), C3 (apply), C4 (analyze), C5 (evaluate), C6 (create), and knowledge dimensions: factual, conceptual, procedural, and metacognitive (Anderson and Krathwohl, 2001). The knowledge dimensions chosen need to be adjusted to the abilities of students which, in this case, are predicted by the ability of their teachers. Students' cognitive development factors (mental and age) are also considered (Czarnocha, et al, 2016). Elementary school students are in the age of 7-12, and based on Piaget's theory of stages of cognitive development, students at the age of 7-11 are in the concrete operational stage, and those aged 8-11 are in the formal operational stage. At the age of $7-8$, students will develop the ability to retain memories of things. At the age of 9-10 years, students sharpen memories about space, learn to sort (classification), and sequence things (seriation). At the age of 11-12, students have begun to think of concrete experiences and think of them as more abstract, idealistic, and logical. At this stage, students begin to imagine possibilities, make speculative thoughts about the ideal quality they want, develop deductive hypotheses about ways to solve problems, and reach conclusions systematically (Mu'min, 2013). Abstract materials can be provided at this stage, at least in grade 5 and 6 of ESs. Therefore, the learning materials need to be arranged based on the characteristics of each stage of students' cognitive development.

In addition, the dimensions of cognitive processes on the learning continuum of biodiversity (level $\mathrm{C} 1$ and $\mathrm{C} 2$ ) are logical in terms of difficulty, complexity, and abstractness. In terms of the level of difficulty, based on the threshold value in each 
item, it is clear that the items suggested to the teacher can still be completed, suggesting a prediction that students can master them as well. From the level of complexity of the materials, ES students should be introduced from simple to complex materials and assessments (Confrey, 2019), according to their initial level of understanding and the development of their cognitive processes. The biodiversity items arranged in the instrument can still be classified at the simple level. Then, based on the consideration of the level of abstractness, ES students are at the stage of concrete operational cognitive development as they can think logically and use reasoning (Andriani and Subali, 2017), but are incapable of thinking abstractly (Mendala et al., 2019). Biodiversity materials given to ES students can be arranged from presenting factual things to finding concepts, although not all students are able to find concepts. Therefore, from the explanation above, this study suggests that the materials at level $\mathrm{C} 1$ and $\mathrm{C} 2$ are logical when given to ES students in Grade 1 to 6 .

To provide comprehensive results, this study held a focus group discussion to obtain respondents' input into the learning continuum prepared at the beginning. Some important FGD results include the following. (1) Because ES teachers are assigned as homeroom teachers who teach almost all subjects, teaching biodiversity materials can be done in an integrated manner with other subjects other than science, like the Indonesian language and Mathematics. This makes possible biodiversity learning can be started from grade 1. (2) Biodiversity materials are already taught in grade 1 , and this starts with individual level diversity, which is to recognize parts of the human body. (2) Students get materials about plants in grade 2 , and this can be enriched with the teaching of plant diversity. (3) Animal diversity has begun to be introduced in grade 4 as they have discussed the structure of animals in science subjects in this grade. (4) Students are introduced to Ecosystems in grade 5, one of them is about animal habitat diversity, so that this can encourage the concept of ecosystem biodiversity. (5) Students have learned simple classifications of animals and plants in grade 5. (6) Grade 6 learning introduces environmental preservation, and this will be effective if it is supported by materials on the diversity of flora and fauna according to the biodiversity zonation in Indonesia. The results of this FGD will be considerations for revising the developed learning continuum as they provide an overview of the implementation of biodiversity learning currently applied in ESs.

In developing the final biodiversity learning continuum (as shown in Table 5), several interesting findings to enumerate include the following. (1) The easiest topic in biodiversity is the diversity of the ecosystem level, then followed by the diversity in humans, animals, and plants. (2) The topic of factors influencing diversity is very difficult, so it would be better to deliver this material by presenting the facts in the student environment, so students can understand it well. (3) In the 2013 Curriculum of ESs in Indonesia, in biology science subject, there seem to be no materials about the diversity of ferns, mosses, algae, and mushrooms, but the results of the survey indicate that the materials are likely to be well understood by the respondents, so this material is possibly worthy of being included in the biodiversity learning continuum. (4) The subtopic of diversity at the organ level can be removed considering that this material is the most difficult, and only a few respondents can complete this. (5) There is one sub-topic 
about Indonesia's zonation biodiversity with the highest difficulty level but still included in the learning continuum because another sub-topic relevant to this sub-topic can be solved by the respondents. Besides, this sub-topic needs to be taught for Indonesian students, to let them know more about Indonesia's biodiversity and participate in conservation actions.

\section{CONCLUSIONS}

This research has successfully developed a learning continuum on Biodiversity topics at the Elementary School level. The development of this learning continuum attentively considered the results of a teacher's cognitive competency survey, FGD, cognitive dimensions and levels, BSCS biology curriculum references, and the stages of student cognitive development. From 32 biodiversity sub-topics in the first draft of the learning continuum, 31 biodiversity sub-topics with cognitive level $\mathrm{C} 1$ and $\mathrm{C} 2$ and cognitive dimensions of facts and concepts knowledge have been brought into its final version. It is expected that this learning continuum can support teachers to appropriately develop their curriculum for more effective learning. The results of this study can be used by biology curriculum developers as a consideration in making curriculum revisions. Biology teachers can also make adjustments to learning biology by following this learning continuum. Other researchers still have the opportunity to develop learning continuum on other biology topics or other subjects.

\section{REFERENCES}

Adams, R.J., \& Kho, S. (1996). Acer quest version 2.1. Camberwell, Victoria: The Australian Council for Educational Research (ACER).

Adawiah, R., Jiwa, M., \& Esa, N. (2015). Student teachers' knowledge of biodiversity. International Journal of Scientific and Research Publications, 5(1), 2250-3153. Retrieved from www.ijsrp.org

Alsubaie, M. A. (2016). Curriculum development: Teacher involvement in curriculum development. Journal of Education and Practice, 7(9), 106-107.

Anderson, L. W., \& Krathwohl, D. R. (2001). A taxonomy for learning, teaching, and assessing: A revision of bloom's taxonomy of educational objectives (L. W. Anderson, D. R. Krathwohl, P. W. Airasian, K. A. Cruikshank, R. E. Mayer, P. R. Pintrich, ... M. C. Wittrock, Eds.). New York: Addison Wesley Longman Inc.

Andriani, A. E., \& Subali, B. (2017). Teachers' opinion about learning continuum based on student's level of competence and specific pedagogical material in classification topics. AIP Conference Proceedings, 1868. https://doi.org/10.1063/1.4995211

Ardiawan, I. K. N. (2017). The correlation between teacher professional competence and natural science learning achievement in elementary school. Journal of Educational Science and Technology (EST), 3(3), 173. https://doi.org/10.26858/est.v3i3.3758

Assaly, I. R., \& Smadi, O. M. (2015). Using bloom's taxonomy to evaluate the cognitive levels of master class textbook's questions. English Language Teaching, 8(5), 100-110. 
https://doi.org/10.5539/elt.v8n5p100

Astuti, L. D., \& Subali, B. (2017). Teacher's opinions about learning continuum based on the student's level of competence and specific pedagogical materials on anatomical aspects. AIP Conference Proceedings, 1868. https://doi.org/10.1063/1.4995215

Blake, B., \& Pope, T. (2008). Developmental psychology: Incorporating Piaget's and Vygotsky's theories in classrooms. Journal of Cross-Disciplinary Perspectives in Education, 1(1), 59-67.

Bond, T. G., \& Fox, C. M. (2017). Applying the rasch model: fundamental measurement in the human sciences. In Journal of Chemical Information and Modeling (Third Edit, Vol. 110). New York and London: Routledge Taylor \& Francis Group.

Bouckaert, M., \& Kools, Q. (2018). Teacher educators as curriculum developers: exploration of a professional role. European Journal of Teacher Education, 41(1), 3249. https://doi.org/10.1080/02619768.2017.1393517

BSCS. (2006). BSCS Biology: A molecular approach. In M. Bloom, S. Getty, \& J. Phillips (Eds.), Mc Graw Hill (9th ed.). Ohio: Mc Graw Hill.

Chandio, M. T., Pandhiani, S. M., \& Iqbal, R. (2017). Bloom's taxonomy: Improving assessment and teaching-learning process. Journal of Education and Educational Development, 3(2), 203-221. https://doi.org/10.22555/joeed.v3i2.1034

Confrey, J. (2019). A synthesis of research on learning trajectories/progressions in mathematics. In Future of education and skills 2030: Curriculum analysis (No. EDU/EDPC(2018)44/ANN3).

Czarnocha, B., Baker, W., Dias, O., \& Prabhu, V. (2016). Two learning trajectories. In The Creative Enterprise of Mathematics Teaching Research: Elements of Methodology and Practice - From Teachers to Teachers (pp. 1-536). https://doi.org/10.1007/978-946300-549-4

Faisal, \& Martin, S. N. (2019). Science education in Indonesia: past, present, and future. Asia-Pacific Science Education, 5(1). https://doi.org/10.1186/s41029-019-0032-0

Fauth, B., Decristan, J., Decker, A. T., Büttner, G., Hardy, I., Klieme, E., \& Kunter, M. (2019). The effects of teacher competence on student outcomes in elementary science education: The mediating role of teaching quality. Teaching and Teacher Education, 86, 102882. https://doi.org/10.1016/j.tate.2019.102882

Förtsch, C., Werner, S., von Kotzebue, L., \& Neuhaus, B. J. (2016). Effects of biology teachers' professional knowledge and cognitive activation on students' achievement. International Journal of Science Education, 38(17), 2642-2666. https://doi.org/10.1080/09500693.2016.1257170

Ibda, F. (2015). Cognitive development: Jean Piaget theory. Intelektualita Volume 3, Nomor 1, Januari-Juni 2015, 3, 27-38.

Ivars, P., Fernández, C., Llinares, S., \& Choy, B. H. (2018). Enhancing noticing: Using 
a hypothetical learning trajectory to improve pre-service primary teachers' professional discourse. Eurasia Journal of Mathematics, Science and Technology Education, 14(11). https://doi.org/10.29333/ejmste/93421

Juniati, E., \& Subali, B. (2017). Teacher's opinion about learning continuum of genetics based on student's level of competence. AIP Conference Proceedings, 1868(August). https://doi.org/10.1063/1.4995212

Kusumawati, M. U., Subali, B., \& Paidi. (2019). Developing a learning continuum of biological resources management aspect from elementary school to senior high school based on the experts' opinions. Journal of Physics: Conference Series, 1397(1). https://doi.org/10.1088/1742-6596/1397/1/012052

Liu, Z. (2016). Inspirations of relevance and spiral curriculum theory for EGP teaching. IOSR Journal of Research \& Method in Education, 6(5), 62-65. https://doi.org/10.9790/7388-0605046265

Mendala, Subali, B., \& Paidi. (2019). Developing a learning continuum on ecological aspect from elementary to senior high school based on the opinions of biology education experts. Journal of Physics: Conference Series, 1397(1). https://doi.org/10.1088/17426596/1397/1/012053

Mu'min, S. A. (2013). Jean Piaget cognitive development teory. Jurnal Al-Ta'dib Vol 6 No 1 Januari-Juni 2013, 6(1), 89-99.

Murray, J. W. (2016). Skills development, habits of mind, and the spiral curriculum: A dialectical approach to undergraduate general education curriculum mapping. Cogent Education, 3(1), 1-19. https://doi.org/10.1080/2331186X.2016.1156807

Orizasativa, L., Subali, B., \& Paidi. (2019). Developing a learning continuum of the pedagogic materials of genetics aspects from elementary school to senior high school level based on the opinions of biology education experts. Journal of Physics: Conference Series, 1397(1). https://doi.org/10.1088/1742-6596/1397/1/012051

Paidi, P., Mercuriani, I. S., \& Subali, B. (2020). Students' competence in cognitive process and knowledge in biology based on curriculum used in Indonesia. International Journal of Instruction, 13(3), 491-510. https://doi.org/10.29333/iji.2020.13334a

Simatwa, E. M. W. (2010). Piaget's theory of intellectual development and its implication for instructional management at pre- secondary school level. Educational Research and Reviews Vol., 5(7), 366-371.

Sinha, A. (2012). The Learning Continuum: formal and informal learning experiences enabling learning and creation of new knowledge in an organization. International Journal of Advanced Corporate Learning (IJAC), 5(2), 10-14. https://doi.org/http://dx.doi.org/10.3991/ijac.v5i2.2111

Sultan, S., \& Shafi, M. (2014). Impact of perceived teachers' competence on students' performance: evidence for mediating/ moderating role of class environment. IManager's Journal on Educational Psychology, 8(1), 10-18. 
https://doi.org/10.26634/jpsy.8.1.2764

Suyanto, S. (2011). Biology learning through 5E learning approach and cycle from BSCS for character building. Prosiding Seminar Nasional " Biology and Local Wisdom; Past, Present And Future," 239-246.

Ulu, E., \& Kiraz, A. (2014). Science education and cognitive development in updated 2012 pre-school curriculum. Procedia - Social and Behavioral Sciences, 136, 438-451. https://doi.org/10.1016/j.sbspro.2014.05.354

Wang, Z., \& Wang, L. (2015). Cognitive development: Child education. International Encyclopedia of the Social \& Behavioral Sciences, 4(December), 38-42. https://doi.org/10.1016/B978-0-08-097086-8.92007-5

Westbury, I., Aspfors, J., Fries, A. V., Hansén, S. E., Ohlhaver, F., Rosenmund, M., \& Sivesind, K. (2016). Organizing curriculum change: an introduction*. Journal of Curriculum Studies, 48(6), 729-743. https://doi.org/10.1080/00220272.2016.1186736

Wilson, J. (2014). Measures of academic progress: The MAP learning continuum. Retrieved from NWEA.org

Yli-Panula, E., Jeronen, E., Lemmetty, P., \& Pauna, A. (2018). Teaching methods in biology promoting biodiversity education. Sustainability (Switzerland), 10(10), 1-18. https://doi.org/10.3390/su10103812

Yuliani, Suryadi, \& Dahlan. (2018). Hypotetical learning trajectory to anticipate mathematics anxiety in algebra learning based on the perspective of didactical situation theory. Journal of Physics: Conference Series, 1013(1). https://doi.org/10.1088/1742$6596 / 1013 / 1 / 012137$ 